\title{
The effect of laser on remanescent liver tissue after $90 \%$ hepatectomy in rats $^{1}$
}

\author{
Efeito do laser no tecido hepático após hepatectomia a 90\% em ratos.
}

\author{
Alexandre Ferreira Oliveira ${ }^{2}$, Tiago Castro e Silva ${ }^{3}$, Ajith Kumar Sankarankutty ${ }^{4}$,Eduardo Garcia Pacheco Juliana $^{5}$ \\ Ferreira $^{6}$, Vanderlei Salvador Bagnato ${ }^{7}$, Sergio Zucoloto ${ }^{8}$, Orlando de Castro e Silva ${ }^{9}$
}

1. Study performed in the Liver Transplantation Unit of the Division of Gastroenterology of the Department of Surgery and Anatomy of Ribeirão Preto Faculty of Medicine (FMRP-USP), and in the in the Physics Institute of São Carlos (IFSC-USP) -University of São Paulo - Brazil.

2. Fellow PhD degree of the Departament of Surgery and Anatomy, (FMRP-USP), Brazil.

3. Graduate Student at the (IFSC-USP), São Paulo, Brazil

4. PhD Professor of Division of Gastroenterology of the Department of Surgery and Anatomy, (FMRP-USP), Brazil.

5. Fellow PhD degree of the Liver Transplant Program of the Division of Gastroenterology of the Department of Surgery and Anatomy, (FMRP-USP), Brazil.

6. Fellow PhD degree of the Department of Pathology, (FMRP-USP), Brazil

7. Full Professor, (IFSC-USP), São Paulo, Brazil.

8. Full Professor of the Department of Pathology, (FMRP-USP), Brazil

9. Full Professor, Head of Division of Gastroenterology of Department of Surgery and Anatomy, Coordinator of the Liver Transplant Program, (FMRP-USP), Brazil

\begin{abstract}
ABSTRATC
Purpose: To evaluate the effect of laser beam on remanescent liver after partial hepatectomy $90 \%$. Methods: Wistar rats, $(\mathrm{N}=42)$, were divided into six groups with seven specimens each. The partial hepatectomy (HP) was performed in all animals through exeresis of approximately $90 \%$ of the liver parenchyma. The animals from groups HP and Laser application, HPL24, HPL48 and HPL 72 undertook laser irradiation carried out through application (dose of $22.5 \mathrm{~J} / \mathrm{cm}^{2}$ ) in five different sites in the remanescent liver. The rats were then sacrificed 24, 48 and 72 hours after HP procedure, for the liver regeneration analysis,using the Proliferating Cell Nuclear Antigen (PCNA), and for dosage of serum aminotransferases. Results: Were demonstrated an increase of the serum levels of alanine aminotransferase for the group of 24 hours and a decrease for the group of 72 hours exposed to laser. The index of marked cells had a considerable more improvement for the group of 72 hours exposed in laser compared to other groups. Conclusion: Laser did not cause hepatic injuries additional to the partial hepatectomy and perhaps led to a benefit by stimulating the proliferative activity.
\end{abstract}

Key words: Liver Regeneration. Acute Liver Failure. Laser. Partial Hepatectomy.

\section{RESUMO}

Objetivo: Avaliar o efeito da luz laser em remanescentes hepáticos após hepatectomia a 90\%. Métodos: Aplicou-se luz laser com comprimento de onda de $660 \mathrm{~nm}$ e potência de $30 \mathrm{mw}$, por 30 segundos, na dose de $22,5 \mathrm{~J} / \mathrm{cm}^{2} \mathrm{em}$ cada um deles, repetidos em cinco pontos do fígado remanescente, após realizada a hepatectomia a $90 \%$. Os animais foram sacrificados para análise do fígado, contagem de hepatócitos em proliferação (Proliferating Cell Nuclear Antigen -PCNA), e coleta de sangue para dosagem serica das aminotransferases, após 24, 48 e 72 horas. Resultado: O índice de células marcadas teve significativo aumento no grupo de 72 horas irradiados com laser. Conclusão: A análise dos resultados demonstrou que o laser não causou lesões hepáticas adicionais à hepatectomia parcial e estimulou a atividade proliferativa hepatocelular. Descritores: Regeneração Hepática. Insuficiência Hepática Aguda. Laser. Hepatectomia parcial.

\section{Introduction}

Acute liver failure (ALF) is a less common condition that afflicts previously healthy people through the development of severe liver dysfunction related to the fast change of the neurological function ${ }^{1}$. Several causes may be recognized as ALF etiological factors, however viral hepatitis is the most common one all over the world, mainly fulminate the virus B hepatitis. Virus and drugs (halothane, acetaminophen isoniazide) are responsible for about $80 \%$ of the cases. Other causes seem to be

related to the region, as for example the intoxication by acetaminophen, which is the most common cause in countries such as England, the United States and Denmark, and practically non-existent in others such as France and India ${ }^{1}$. Experimental models are aimed at studying about liver regeneration (LR), but partial hepatectomy described by Higgins and Anderson ${ }^{2}$ is one of the best published studies. This model outlines the surgical removal of the left lateral and middle lobes of 
the liver of rats, consisting of approximately 67 to $70 \%$ of the total liver mass of these animals. Right lateral and tailed (posterior lobes) remain intact, which correspond to approximately $24 \%$ and $9 \%$ of the total liver mass. Well-standardized 70\% hepatectomy allowed the increase of the resection level to $90 \%$, but with high death rates. Gaub and Iversen were able to make possible the subtotal hepatectomy technique at $90 \%$ by means of post surgical support, thus permitting the use of the model in IHA and RH studies ${ }^{2,3,4}$. During the regenerative process there is a proliferation of all liver cells, though most of the studies focus on the hepatocytes, for these constitute around $90 \%$ of the liver mass and $60 \%$ of the whole cell number ${ }^{4}$. After partial hepatectomy there is the activation of 70 or more genes, which is the first step of event cascade that guides the DNA synthesis. Hepatocytes leave the rest state of the cellular cycle (G0), go through the G1 phase and start the DNA synthesis or S phase (10 to 14 hours after the hepatectomy) with the occurrence of the first peak at the $24^{\text {th }}$ hours and the second peak between the $36^{\text {th }}$ and $48^{\text {th }}$ hour ${ }^{4,5,6}$. LASER is an acronym in English that stands for, light amplification by stimulated emission of radiation. As to its action on the liver parenchyma we suppose that the LASER light carries the conformational changes in the structure of the hepatocyte_cytochrome so that there would be an increase in ATP production, expressing an augmentation in the liver energetic metabolism of hepatectomized rats ${ }^{7,8,9}$. This paper has the objective to analyze the photo-bio-stimulating effect of the LASER light on the regeneration of the remanescent liver tissue after hepatectomy $90 \%$.

\section{Methods}

Forty-two male, Rattus norvegicus, lineage Wistar rats, apparently healthy, with body weight between 240 and 300 grams, from the Animal Colony of Ribeirão Preto Faculty of Medicine - University of São Paulo - (FMRPUSP), were used and kept under controlled conditions. Wistar rats, $(\mathrm{N}=42)$, were divided into six groups with seven specimens each. The hepatectomy was carried out through exeresis of approximately $90 \%$ of the liver parenchyma $^{2,3}$. Before the synthesis of the abdominal wall, the animals from groups HPL24, HPL48 and HPL 72 undertook laser irradiation carried out through application (dose of $22.5 \mathrm{~J} / \mathrm{cm}^{2}$ ) in five different sites for 30 seconds in each one of them in the remanescent liver. The equipment for the laser light transmission used was that of low potency BDP 660 (MM Optics Ltda., São Carlos - SP) of continuous emission classified as IIIb, which has as active medium the semiconductor, wavelength of $660 \mathrm{~nm}$ (visible / red), adjusted with potency of $30 \mathrm{~mW}$. The animals were sacrificed at 24,48 and 72 hours after the first surgical intervention according to what is described in the experiment outline. After anesthesia, the abdominal wall was widely open and collected $2 \mathrm{ml}$ of blood through low cava vein punction for biochemical dosages of the aminotransfereases. Small liver fragment was collected for analysis of the liver regeneration.

\section{Serum aminotransferases}

Blood samples $(4 \mathrm{ml})$ were placed in a container without previous anticoagulant treatment. Aspartate aminotransferase and alanine aminotransferase activities in serum (AST and ALT, respectively) were determined by conventional procedures using a commercial spectrophotometer (Model E2250-CELM) ${ }^{10}$

\section{Liver regeneration analysis}

Liver regeneration was evaluated by immunohistochemical staining for proliferating cell nuclear antigen (PCNA) using monoclonal primary antiPCNA antibody (PC-10; DAKO A/S, Glostrup, Denmark) on formalin-fixed and paraffin-embedded liver tissues. Sections were cut at $4 \mu \mathrm{m}$, mounted on poly-L-lysinecoated glass slides, deparaffinized, rehydrated in an increasing alcohol series, placed in phosphate-buffered saline (PBS), and treated with $2 \%$ hydrogen peroxide in methanol for $15 \mathrm{~min}$ to block endogenous peroxidase activity $^{8}$. Nonspecific protein binding was blocked by pre-incubation with 5\% normal horse serum diluted in PBS for $30 \mathrm{~min}$. This was followed by incubation with PC-10 monoclonal primary antibody, diluted 1:40 in PBS for $120 \mathrm{~min}$ at $25^{\circ} \mathrm{C}$. The sections were then incubated for 35 min with a biotinylated horse antimouse immunoglobulin. The reaction product was detected with an avidin-biotin-peroxidase complex and diaminobenzidine was used as a chromogen substrate. Positive and negative controls were used to assess and control the staining procedure. Sections were examined blindly at high power (400X), and 20 fields were chosen at random. Nuclear labeling indices for PCNA (positive nuclei/total number of counted nuclei) were determined by evaluation of at least 1,000 hepatocyte nuclei ${ }^{8}$. In order to accomplish the overall comparison among the several studied groups we used the non-parametric test of Kruskal-Wallis. The significance level considered was 0.05 . For comparison between the two sacrificed groups within 24 hours (with and without LASER irradiation), 48 hours (with and without LASER irradiation) and 72 hours (with and without LASER irradiation), we made use the non-parametric $U$ test of Mann-Whitney. The significance level considered in these tests was 0.05 .

\section{Results}

In relation to ALT, significant statistical differences were found among the 24-hour groups and the 72-hour groups. In the 24-hour groups there was an increase in the ALT serum levels in the LASER-irradiated group. However, in the 72-hour groups there was a reduction in the alt serum levels in the LASER-irradiated groups (table 1). In relation to AST there were no significant statistical differences among the different studied groups. As to indexes of marked cells, we found significant statistical differences among the 72-hour groups. For these groups there was an increase in the marked cells index in the LASER-irradiated group. In the remainder of the groups, there were no significant differences. 
TABLE 1 - Values of ALT, AST, DHL and marked cell indexes (average \pm standard deviation) in the different studied groups.

\begin{tabular}{lcccc}
\hline & ALT & AST & LDH & $\begin{array}{c}\text { Marked cell } \\
\text { indexes }\end{array}$ \\
\hline HP 24 & $716 \pm 139$ & $964 \pm 257$ & $917 \pm 671$ & $0,327 \pm 0,022$ \\
HPL 24 & $1123 \pm 364$ & $1181 \pm 366$ & $768 \pm 237$ & $0,317 \pm 0,010$ \\
HP 48 & $302 \pm 140$ & $494 \pm 156$ & $1852 \pm 1191$ & $0,325 \pm 0,045$ \\
HPL 48 & $334 \pm 165$ & $564 \pm 211$ & $1273 \pm 576$ & $0,332 \pm 0,020$ \\
HP 72 & $162 \pm 23$ & $320 \pm 36$ & $1067 \pm 1100$ & $0,314 \pm 0,021$ \\
HPL 72 & $111 \pm 22$ & $303 \pm 97$ & $968 \pm 430$ & $0,383 \pm 0,014 *$ \\
\hline
\end{tabular}

HPL 72 vs HP $72 \mathrm{p}<0.05$

\section{Discussion}

Liver regeneration has been studied in several aspects and the most puzzling question is how the regenerative process is triggered, because contrary to the cells that constitute renovating tissues, the hepatocytes are at rest in the G0 phase of the cellular cycle ${ }^{5,6,9}$. Experiments with growing factor infusion (HGF, alpha-TGF and EGF) in the portal circulation of normal rats reveal that only $10 \%$ of hepatocytes turn to synthesize DNA, but if the same infusion is preceded by hepatectomy 30\%, the administration of colegenase via portal or even hepatotoxic drugs, the proliferative response becomes very intense, showing that the hepatocytes must be first habilitated before the regenerative activity ${ }^{5,6}$. Studies reveal that the capacitation of the hepatocytes constitute a reversible process and is not sufficient to induce DNA replication, and that the main regulatory step for cellular replication might not be the capacitation period, but mainly the hepatocyte progression until the DNA synthesis ${ }^{6}$. The activity of several mitogenic cells was compared in different levels of hepatectomy (30, 70 and 90\%) and it was seen through the detection of nuclear antigen Ki-67 that the larger the resection the greater the mitotic activity of the remanescent parenchyma ${ }^{11}$. After partial hepatectomy, the liver remanescent (LR) undergoes a metabolic overcharge (MO) that is more intense according to the resection level. This MO occurs because the LR needs undergo hemodynamic adaptation (parenchyma reduction and maintenance of the portal and arterial blood flow), need to keep the liver metabolism intact and still regenerates ${ }^{8}$. Application of low potency laser light on rat liver, with focus on the biochemical parameters related to regeneration, as well as the analysis of histological indicators of mitosis was demonstrated that the mitotic index rises to $15 \%$ in hepatectomies without laser application for $50 \%$ when followed by illumination ${ }^{8}$. The same group showed that the argon-laser application with $590 \mathrm{~nm}$ wavelength and $50 \mathrm{mw} /$ $\mathrm{cm}^{2}$ power on the liver remanescent of rats subjected to hepatectomy $70 \%$ and $90 \% \%^{7,8}$ present elevation of state three of mitochondrial breathing, as well as an increase of the mitosis number in the first 24 hours. Studies have shown that low potency laser (LPL) significantly increased both the bloodstream flow in the ungueal bed and the mesenteric capillary flow ${ }^{12-}$.With the promising findings we decided to study the cellular proliferation level in rats subjected to hepatectomy $90 \%$ that represents an experimental model of acute liver insufficiency (ALI) and to check the results through PCNA and evaluate also the biochemical and enzymatic patterns. Biochemical and enzymatic tests are important in the evaluation process of IHA and liver regeneration because they are useful for the diagnosis, prognosis and monitoring of the therapeutic response ${ }^{10,11,12,13}$. Aminotransferases ALT and AST are enzymes whose synthesis takes place in the liver, kidney, heart muscle, pancreas, skeleton muscle and brain. Both are intracellular enzymes, but AST is mainly located in the cytoplasm and is present in a smaller concentration in the mitochondrias. A ALT is exclusively located in the cytoplasm. Aminotransferases are usually present in low concentration serum, and their absolute values and/or ratio ALT/AST may serve as indicators for hepatic-cellular integrity. Therefore, ALT elevation is an indicator of more specific liver damage. ${ }^{8,9,11}$ Hepatectomy $90 \%$ had a course with elevated levels of AST and ALT in the first 24 hours that was followed by subsequent decline in the 48- and 72hour groups, and as to the laser application there was a significant elevation of ALT in the 24 HPL group when compared to $24 \mathrm{HP}$ group and a significant reduction of this in the 72 HPL when compared to the $72 \mathrm{HP}$, which shows that the laser in the first moment increases the metabolic overcharge preparing the liver parenchyma for a marked regeneration that will take place later and improve the liver regeneration prognosis. A few immunohistochemical methods have been used to assess the LASER action on the liver tissue in the phase of cellular proliferation ${ }^{9,14,15}$ .The present study showed that in the 72 HPL group when compared to the $72 \mathrm{HP}$ group, the number of marked cells was significantly greater, and this shows that laser prepares the LR for a more intense regeneration as the SM becomes more attenuated. Laser may bring important advances concerning the stimulation of liver regeneration in IHA helping in the metabolic recovery of LR and in its proliferation. Therefore, in the experimental conditions of the current paper it was verified that laser had significantly stimulated the liver regeneration after partial hepatectomy $90 \%$ in the 72-hour group without inducing further hepaticcellular damage to that induced by hepatectomy per si. 


\section{References}

1. Williams R, Riordan SM. Schiff's diseases of the liver. $9^{\text {th }}$ ed. Philadelphia: Lippincott Williams \& Wilkins, 2003.

2. Higgins GM, Anderson RM. Experimental pathology of the liver. Restoration of the liver of the white rat following partial surgical removal. Arch Pathol. 1931;12:186-202.

3. Gaub J, Iversen J. Rat liver regeneration after $90 \%$ partial hepatectomy. Hepatology. 1984;4:902-4.

4. Alison MR. Regulation of hepatic growth. Physil Rev. 1986;66:499-541.

5. Michalopoulos GK, De Frances MC. Liver Regeneration: molecular mechanism of growth control. FASEB J. 1990; 4:176-87.

6. Fausto, F. Liver regeneration. J Hepatol. 32: 19-31, 2000.

7. Brasil IRC. Efeito da luz Laser sobre o remanescente hepático de ratos submetido a hepatectomia 90\%. [Tese - Doutorado]. Universidade de São Paulo - Faculdade de Medicina de Ribeirão Preto; 2002.

8. Castro e Silva Jr O, Zucoloto S, Bagnato VS. Laser enhanced effect in hepatic regeneration after hepatectomy in rats. Laser Surg Med. 2001;28:1-5.
9. Ozawa K. Liver Surgery Approached Through the Mitochondria. Tokyo: Medical Tribune Inc.; 1992.

10. Reichling JJ, Kaplan MM. Clinical use of serum enzymes in liver disease. Dig Dis Sci. 1988;33:1601-14.

11. Sakaguchi K, Takeuchi E, Suzuki M, Oda K, Nagino M, Nimura Y, Yoshida S. ADN polymerases and Ki-67 nuclear antigen are induced in correlation with the resected mass o rat liver up to $90 \%$. Langenbecks Arch Surg. 2000; 385:135-42.

12. Miro L. Estudio capilaroscópico de la acción de un laser AsGa sobre la microcirculación. Investig Clin Laser. 1984; 12:9-14.

13. Jalan R, Sen S, Stoiner C, Kapjor D, Aur A. Extracorporeal liver support with molecular adsorbents recirculating system in patients with severe acute alcoholic hepatitis. J Hepatol. 2003;38:24-31.

14. Ohmori S. Clinical characteristics and prognostic indicators of drug-induced fulminant hepatic failure. Hepato-Gastroenterology. 2003; 50:1531-4.

15. Assy N, Gong Y, Zhang M, Pettigrew NM, Pashniak D, Minuk GY. Use of proliferating cell nuclear antigen as a marker of liver regeneration after partial hepatectomy in rats. J Lab Clin Med. 1998;131:251-6.

\section{Correspondence:}

Orlando de Castro e Silva Jr.

Rua Campos Salles, 809/9 andar

14015-110 Ribeirão Preto - SP Brazil

orlando@fmrp.usp.br
Conflict of interest: none

Financial source: FAPESP, CNPq and CAPES

\section{How to cite this article:}

Oliveira AF, Castro e Silva T, Sankarankutty AK, Pacheco EG, Ferreira J, BagnatoVS, Zucoloto S, Castro e Silva O. The effect of laser on remanescent liver tissue after 90\% hepatectomy in rats. Acta Cir Bras. [serial on the Internet] 2006;21 Suppl 1. Available from URL: http://www.scielo.br/acb 